\title{
I was Born Black and Female: A Womanist Reading of Lorraine Hansberry's A Raisin in the Sun
}

\author{
Hana' Khalief Ghani \\ Department of Translation, College of Arts, University of Al-Mustansiriya, Iraq \\ Email: hanaakhleif@yahoo.com
}

\begin{abstract}
I was born black and female,' Lorraine Hansberry once said. These two identities dominated her life and writings. Rejecting the limits placed on her race and gender, Hansberry employed her writings to investigate what it meant to be a black woman in post-war America. Throughout history, black women suffer various forms of marginalization, discrimination, and oppression. The same is true of their position in literature. Because of the white monopoly of literary writing and production, black women were underrepresented in the dominant white literary canon. Hence the need to have a distinctive voice of their own. As a literary movement, Womanism tries to give black women that voice. It addresses the triple impact of race, sex, and class on black women. Lorraine Hansberry's $A$ Raisin in the Sun (1959) deals with a number of womanist issues like black man-black woman relationship, gender roles, images of black woman in the 1950s American society, black matriarchy and abortion. It centers around three black women as they grapple with the difficult circumstances they are facing in a largely white racist society.
\end{abstract}

Index Terms - womanism, black woman, Lorraine Hansberry, A Raisin in the Sun

The history of woman is largely the history of man. History writing itself is a typical man's activity. It constituted a "masculine tradition, written by men, devoted to the deeds of men, glorifying the masculine virtues of courage, honor, and patriotism, and dedicated to preserving the names of past heroes and recording patriarchal genealogies" (Rackin, 1985, p.329). Consequently, within that historical record, women had no place.

This results in the division of life into two distinctive sections: public and private. The feminist analysis proves this division to be gender-specific, i.e., the public life is the property of men and women are relegated to the invisible private sphere. (Rose in Mitchell \& Oakley, 1989, pp.173-4) This leads to the confinement of women to the world of domestic labor, child bearing and concomitant sexual activities. (See Case, 1985)

These stereotypical images of women as wives, mothers, daughters or lovers are largely the product of a maledominated society as Fergusson (1977, p.7) believes.

More important- since this paper deals with a dramatic work- these images are not confined to public life; they pervade the world of stage too. In relation to this, Gillian Hanna rightly observes:

Rarely were we able to play women who lived on stage in their own right. We were always someone's wife, mother or lover. (Someone being a man, of course.) Our theatrical identity was usually defined in terms of our relationship to the (more important) male characters. We only had an existence at all because we were attached to a man. (qtd. in Aston, 1999, p.7)

Generally speaking, feminist movements locate the oppression and subordination of women, which is seen to be historically extremely common and widespread, in the patriarchal domination of women by men. (Fortier, 2002, p.108) In fact, they share the basic view that "western civilization is pervasively patriarchal and is organized and conducted in such a way as to subordinate women to men in all cultural domains: familial, religious, political, economic, social, legal and artistic" (Abrams, 1999, pp.234-5).

Understandably, patriarchy comes under severe attack and criticism by the feminists for the role it plays in hindering women from realizing their creative possibilities. In A Room of Her Own (1929) and The Second Sex (1949), both Virginia Woolf and Simone de Beauvoire respectively made a detailed analysis of women's oppression within the patriarchal system. Both declare that women should establish and define for themselves their own identity by "challenging the existing false cultural notions about their gender identity and develop a female discourse that will accurately portray their relationship to the world of reality and not to the world of men" (Bressler, 2007, pp. 172-3). Furthermore, Beauvoire's analysis focuses on the social construction of women as the Other. This Beauvoire identifies as fundamental to women's oppression. She believed that discrimination against women happened on the basis of such categories of identity as race, class, and religion. But she said that it was nowhere more true than with sex in which men stereotyped women and used it as an excuse to organize society into patriarchy (See Changefoot, 2006).

Hence, it is quite natural that The Second Sex encourages the idea of women fighting for equality with men and emancipation. In relation to these goals, Beauvoire implicitly shows that emancipation of women is an ongoing endeavor; one that can not be completed as a project in the present. (Ibid., p.11) 
Inspired by the efforts and calls of the first wave of feminists like Woolf and Beauvoire and influenced by the dramatic changes that took place in the western world in the wake of WWII, women began to demand equal rights with men, agitating specifically on the issues of equal pay, equal civil rights, equal access to education, health, legal rights, decent housing, free contraception and abortion on demand (Weedon, 1987, p.1).

Accordingly, being a "theoretical and political practice committed to the struggle against patriarchy and sexism," as Toril Moi pronounces (qtd. in Campell, 1994, p.5), Feminism is specifically directed at changing existing power relations between men and women so as to empower women and free them from all the manacles that hinder the release of their potentials. (Weedon, 1987, p.1)

However, the situation of women becomes more complicated in the case of black women whose position has been described and written by white authors. Because of that , Sue-Ellen Case remarks "the [resulting] discourse is necessarily distanced from the actual experiences that shape this position" (In Fortier, 2002, p.115). Moreover, "This distance is not an objective distance, but one which reflects a perspective of racial and class privilege" (Ibid). In fact, because black women have a different relation than white women do to the white male canon, and to the hegemonic white discourses, white authors, Case contends, can not write from the perspective of the ethnic communities or the experience of racial oppressions (Ibid.).

It is a well-known fact that black women's experience of oppression was and is triply grounded in gender, class and race. In "Ain't I a Woman," (1982), the black American activist, Bell Hooks, asserts the need of Feminist Movement to address the needs of women from all classes and races.(qtd. in Aston, 1995, p.79) Here Hooks encourages black women to recognize the special vantage point their marginality gives them and she urges them to make use of this perspective to "criticize the dominant racist, classist, sexist hegemony as well as to envision and create a counter hegemony" (Ibid.).

This desire to create a black "counter hegemony" is realized through the establishment of "Womanism" which is a special kind of [black] feminist theory that aims at answering the needs of black women and their struggle to transform the patriarchal and racial system this minority has historically experienced. Coined by the American novelist, Alice Walker, in her seminal book, In Search of our Mothers' Gardens: Womanist Prose Since 1983 (1983), Womanism is the black equivalent to mainstream feminism. However, Walker makes it clear that womanism can only be differentiated from feminism by the additional factor of color/race ( See Womanism, 2007).

In fact, there are more definitions of womanism than that of Walker. According to the Oxford Companion of AfricanAmerican literature, "Womanism is generally understood to address the triple impact of race, sex, and class on AfricanAmerican women and to compensate for the traditional shortcomings of feminist discourse that has routinely excluded the peculiar needs of African-American women" (Ibid.).

This definition underlies the special position of black women and emphasizes the fact that black women, in contrast to white women, additionally to their oppression in terms of gender and class, have to overcome disadvantages because of their race. (Ibid.) It also emphasizes that black women do not only have to face discrimination because of their cultural and social backgrounds like black men, but they are discriminated because of the fact that they are women as well.

Accordingly, womanism is often used as a means for analyzing black women's literature, as it marks the place where race, class, gender, and sexuality intersected. It is unique because it does not necessarily imply any political position or value system other than the honoring of black women's strength and experiences (Ibid.).

As for womanist theatre, it is constructed around major precepts of feminist, Afrocentric, and post-Afrocentric theatre theory, resulting in a reshaping of dramatic form and narrative (Giles, 2005, p.1). Like feminist theatre, womanist theatre subverts traditional Eurocentric dramatic structures to expose patriarchal misrepresentation, bias, and oppression. It also seeks to place women characters in the 'subject position,' (Ibid.) and to raise their consciousness as to their rights and potentials.

Although the term 'womansim' was not coined until the early 1980s, its concepts and interests appeared in many literary works before that time. One such work is Lorraine Hansberry's (1930-1965) A Raisin in the Sun (1959) (Henceforth A Raisin). Since Hansberry believes that "Black women are a prism through which the searing rays of race, class and sex are first focused, them refracted," (Ibid.) she sets out to transform these rays into a "spectrum of brilliant colors, a rainbow" which illuminates not only the experience of black women, but also of all mankind. (Ibid) In her powerful drama, Hansberry depicts the unique range of experiences of three black women negotiating their ways through a Eurandrocentric society.

Besides being an examination of the impact of racial discrimination on the life of an ordinary, working class family in the 1950s, the play displays a very strong view on a number of womanist issues that would transpire during the decade following its initial production and beyond. It raises the issues of black man-black woman relationship, gender roles, women's right to education and better living conditions, the role of male in the black matriarchal society, black woman's identity, poverty, and abortion.

All the characters in A Raisin have unfulfilled dreams. These dreams mostly involve money. Noteworthy is the fact that although the Younger family seems alienated from and oppressed by white middle-class society, they harbor the same materialistic dreams as the rest of the American society. In the 1950s, the stereotypical American dream was to have a house with a yard, a car and a big family. 
In the play, Lena tries to realize this dream when she uses a life insurance money to move from the overcrowded and overpriced region the family is living in into Claybourne Park, a white-dominated city in the suburbs.

Hansberry expresses early in the play that the three women; Lena, Ruth, and Beneatha, are the backbone of the social organization of the Younger family whether they realize it or not. Two of them, Lena and her daughter-in-law, Ruth, have shouldered the burdens of home-makers, maternal care and domestic workers. Hard though it is, they are struggling to live up to this multiple roles ideal. Moreover, both are partners in the management of economic and domestic affairs.

Lena or Mama as she is often referred to in the play is the ultimate support and final word in the house. After her husband's -Big Walter- death, she becomes the matriarch of the Younger family. In her Stage(d) Mothers: MotherDaughter Tropes in Twentieth Century American Drama, Hanson (2006) divides the mothers on the American stage into four main types. They are the monstrous mother, the saintly mother, the absent mother, and the mirroring mother.

Hansberry's play makes it crystal clear that Mama belongs to the category of saintly mother who is characterized by her willingness to suffer for her children. Furthermore, this mother is often defined by herself and others through her role as a mother rather than as a woman with multiple demands and conflicting interests. (Ibid, p. 123) Noteworthy, although she was seen by audiences, particularly whites, and critics alike, as a "familiar figure from the American literary and dramatic canon: the dark-skinned, white-haired, conservative Mammy of the good old days...who struggled to keep her unruly children in the line,"(Elam and Krasner, 2001. p.42) it is evident, Lisa M. Andeson asserts, that Mama is a "1959s reality-based example of the nurturing, protecting and fighting black woman" (qtd in Hanson, 2006, p.141). In the play, Mama fights to save her children from the enclosure of the ghettoes of Chicago which she sees as a danger to their health and happiness. Noteworthy here is Hansberry's dedication of A Raisin to her mother. Her dedication, "To Mama: In Gratitude for the Dream" is quiet significant in the light of Hansberry's concern with the dilemmas of black women in America. In fact, Hansberry's mother was a source of inspiration for her and a model worthy of emulation. She follows her mother's lead in fighting the racist policies that targeted the black race. Both call for the emancipation of the black race from all the manacles that prevent them from the realization of their dreams of equal chances in housing, education and work (See Ghani, 2011, p.610).

Mama's greatest desire is to move away from the crumpled apartment in which she lives with her family into a house with a garden in the suburbs. Walter, her son, does not share her dream and conflict arises between them over how best to spend the money. In an attempt to convince him of the importance of her decision, Mama states the reasons behind her insistence on buying a bigger house. She says

I- I just seen my family falling apart today...just falling to pieces in front of my eyes...We couldn't of gone on like we was today. We was going backwards 'stead of forwards-talking 'bout killing babies and wishing each other was dead... when it gets like that in life--you just got to do something different,...I wish you'd say how deep inside you you think I done the right thing. (Hansberry, 1960, p.165) (All subsequent quotations refer to this edition)

Therefore, it is not hard to see why Mama belongs to the group of mothers who are supremely self-sacrificing. To this, Anderson concurs:

The money that comes to the family does technically belong to Mama... She could have used all of the money on herself [traveling to Europe or buy expensive clothes], as Ruth suggests early in the play, but she chooses to give part of it to her children to help make their lives easier. In this, she embodies the self-sacrificing mother figure. (qtd. in Hanson, 2006, p.143)

In the same vein, Reed (2001) believes that Mama incorporates in her character almost all the 'descriptors' which Clenora Hudson-Weems deems essential in the African womanist for Mama is self-namer, family-centered, genuine in sisterhood, strong, whole, authentic, a flexible role player, respected, spiritual, adaptable, mothering, nurturing and in concert with the African man in struggle. (p.17)

These points determine Mama's relationship with her son, Walter, and with the other two women in the family; Ruth and her daughter, Beneatha. Although Mama loves them all and earnestly wants to help making their dreams come true, it is obvious that her treatment of her son is different from her treatment of her daughter. This difference in treatment, Neal A. Lester (2003) remarks, reflects Mama's gender bias (in Fisher and Silber, p.246). In fact, Mama is able to find her power within the patriarchal family structure around her. Though a male no longer heads the family, Mama rules the household in the place of her late husband. Her custody of the family is only temporary; she holds power only until she deems her son to have risen to the level of maturity wherein she can hand him over the reins. She does so at the end of the play, when Walter- in spite of his losing his share in the insurance money- rejects the money the racist Mr. Karl Linder tries to give the Younger family to convince them to stay where they are and not buy the house in the suburbs (Hanson, 2006, p.144). Mama compares Walter's decision here as worthy of his father, and in doing so, she passes the power over the family to her son. Thus Mama, Hanson argues, seems to "perpetuate the patriarchal family system" (Ibid.). In fact, Mama works to mold Walter into a "responsible man." She agrees to entrust him with a significant portion of the insurance money. She said "Take the money-Be the head of this family from now on like you supposed to be" (p.170) as she pushes him to be the patriarchal head of the family. More important, Walter's "initiation" into black manhood is orchestrated by Mama's manipulation. She allows Travis, Walter's son, to witness his father's action with Linder. She embarrasses Walter into making the decision she deems necessary, i.e. resisting the white racist policies in housing that aim at imprisoning the blacks in their ghettoized districts. Her self-congratulatory comment 
about Walter to Ruth and Beneatha at Linder's departure- "He finally come into his manhood today, didn't he?"(p205) signals , Lester (2003) argues, the play's “climax for Mama as Walter's action allegedly demonstrates his personal integrity and the cultural dignity of African-Americans like his deceased father, who, according to Mama, gave his all to provide for his family" (qtd in Fisher and Silber, p.246). It is obvious that the values of patriarchy guide Mama's actions and thinking. Although she does not oppose Beneatha's dream of becoming a doctor or her decision to decline the wealthy George Murchison's proposal, she attaches little seriousness to Beneatha's move toward adulthood. In fact, she focuses more on Walter's life and problems. Moreover, from subtle comments about Travis's bedmaking- "He's a little boy. Ain't supposed to know 'bout housekeeping" (p.120) -to her behavior with Beneatha when the latter challenges her beliefs about God: "It don't sound nice for a young girl to say things like that" (p.128)- Mama, Lester asserts, seems to support "deeply entrenched gender roles" (in ibid., 248). This seems understandable since Mama is the product of the Great Migration and the first half of the twentieth century which is characterized by its conservative attitudes regarding the roles men and women should play within the social and cultural context of that period. However, Anthony Barthlemey believes that the end of the play makes A Raisin an 'endorsement of patriarchy' not at the expense of female strength or female governance [since] manhood in A Raisin is wholly compatible with [womanism]" (in Koloze, 2005, p.3-4). Mama does not surrender judgment to Walter simply because he is a man; she acquiesces because Walter is right. Manhood can not be achieved until Walter demonstrates the pride and dignity that the women of the Younger family already possess.

Walter is a frustrated and restless chauffeur who desires the opportunities that the white men have. More than anything, Walter is consumed with envy and rage because of the disparities that existed between black people and whites during the 1950s in America. He is "wracked up with bitterness" (p.157) as Murchison, Beneatha's boy friend, described him.

After the death of his father, Walter becomes the man of the house but he feels he is not acting as he should be. The family has no money and he hasn't been able to provide a better life for them. Of this, he complains to his wife, Ruth: "I am thirty five years old; I been married eleven years and I got a boy who sleeps in the living room-- and all I got to give him is stories about how rich white people live" (p.115). It is this knowledge that underlies his bitter disgust and selfcontempt. These feelings towards himself affect the relationship that Walter has with each member of his family and the way he interacts with them.

Walter believes that being rich is the only solution to his family's problems. Despite his mother and wife's protestations, he insists on equating money with life. As such, his manhood, Lester (2003), believes, is based on economics and relegating women in his home to a secondary position of importance in his personal dream. (In Fisher and Silber, p.246) Walter assumes that his limited socio-economic position results from having unsupportive black women. He says: "A man needs a woman to back him up...We one group of men tied to a race of women with small minds" (pp.113-116). Walter's character here is meant to represent a kind of broken frustrated masculinity that white society perceived among black men of the 1950s; men who were shut out of the American dream by racism and poverty. Because of this exclusion, Walter's dreams of money becomes inextricably linked to his image of himself as a man.

Walter believes that Ruth and Mama should not work since it makes him look cowardly. Ruth and Mama want to support the family by cooking and cleaning the houses of the white people in the neighborhood. As a matter of fact, Walter's discrimination against Ruth and Mama is a sign of the times. Women in America did not commonly work in the 1950s and 1960s. The women were generally in charge of taking care of the children and the house.

Accordingly, Ruth and Mama's work as domestic laborers is a subversion of the gender roles in Walter's opinion. The vicious cycle of poverty and the difficulty of getting good-paid jobs for the black males impose responsibilities on black women that were "contrary to the conventional feminine roles, granting them a perceived dominance over black men" (Coleman, 2003, p.47). This dilemma is well summed up by Doris Y. Wilkinson and Ronald Taylor in The Black Male in America: Perspectives on his Status in Contemporary Society (1977):

Through...systemic denial of an opportunity to work for the black men, white America thrust the black woman in the role of family provider. This pattern of female-headed families was reinforced by the marginal economic position of the black male. (qtd in ibid., p. 47)

Through working outside and inside home, Bolton (2000) believes that both Mama and Ruth experience 'the third shift' which is a "widespread [womanist] phenomenon today precisely because we live in an era of social transition, when gender roles for women are in enormous flux" (pp.8-9). Like other black women, Mama and Ruth are expected to fulfill significant responsibilities and leadership roles at work and also retain a nurturing, other-oriented role in the family and broader community. (Ibid., p.9)

As for Walter-Ruth relationship, it is evident from the first scene that there is something wrong between them. They are short and impatient with each other. Ruth is tired of listening to her husband talk. She tells him to leave her alone three different times after asking him not to talk about anything money-related. "You get your mind off money and eat your breakfast," (p.109) she says to him. Yet Walter continues talking. Finally he sees the way his wife feels as he asks her, "You tired, ain't you? Tired of me, the boy, the way we live- this beat-up hole-every thing, Ain't you" (p.113).

With the rants of Walter, sexism is also very evident in the opening scene. Walter opens the play in a dialogue with his wife telling her "This is just what is wrong with the colored woman in this world...Don't understand about building their men up and making 'em feel like they somebody. Like they can do something" (p.115), (Looking at his wife and 
his sister ...very sadly) The world's most backward race of people, and that's a fact"(p.119), and "Here I am a giantsurrounded by ants! Ants who can't even understand what it is the giant is talking about,'(p.157) because they don't support him. Hence, Walter provides the supporting rhetoric for his place as the patriarchal head of the family. He enforces his patriarchal aspiration as he defiantly gives his son the money for school that Ruth, his wife, denies for possibly economic reasons. Here Walter's attempts to assert his manhood highlights a "white patriarchal cultural script from which he reads and endeavors to follow- providing Travis and Ruth with illusory symbols of living the 'American dream"' (Lester in Fisher and Silber, 2003, p.246).

More important, Walter wants his son to have a better life than he has and wants to provide him with the education he deserves. In fact, he seems to care more for Travis's education than for his sister, Beneatha's, partly because Travis is his son and partly because Beneatha is a woman. Here Hansberry reflects her belief that within the marginalized group of black exists the even more marginalized group of black women who have to fight with prejudice across racial and gender lines. Obviously the women, according to Hansberry, are "the most oppressed of any oppressed group...and if you've got an oppressed group, [women] are oppressed twice" (Terkel, 1979, p.251). Walter denies Beneatha's dream of becoming a doctor. He says "Who the hell told you you had to be a doctor? If you crazy 'bout messing 'round with sick people- then go be a nurse like other women- or just get married and be quiet"(p.118). Whether consciously or not, Walter is acting as if his and his son's interests are more important than Beneatha's even though Beneatha has proven she is intellectually capable. Walter believes that the insurance money Mama gives to him can provide him with financial success and educational resources for his son, a priority he values more highly than his sister's goal of becoming a doctor.

Ruth Younger is the most selfless, self-sacrificing, and emotionally balanced character. She is a peacemaker between Walter and Beneatha and a bridge between Mama and Walter. The small income she earns from working as domestic laborer is essential for the desperately needed upkeep of the family. Moreover, the multiple roles she plays inside and outside home make her life really exhausting. Hansberry's description of her in the stage direction testifies to this:

Ruth is about thirty...she was a pretty girl...but now it is apparent that life has been little that she expected, and disappointment has already begun to hang in her face. In a few years, before thirty-five even, she will be known among her people as a "settled woman." (p.106)

This somehow gloomy portrayal does not mean Ruth lacks spirit or strength. Like other black married women, Ruth is in the middle, torn between the needs and dreams of others and her own humble aspiration to live peacefully. Like them, she subordinates herself because she is left with no other choices.

These conditions prove highly burdensome for Ruth as a black woman in a society that highly discriminates against the blacks. Commenting on this, Ryan (1975) remarks that black women like Ruth still carry the heavier burden, "Still, the fact remains that it is the black woman of America who is most likely to experience the worst of urban poverty, which brutally overtaxes her in the roles of wife, worker, and mother" (p.381).

When the play opens, Ruth is the first person to get up and after some noticeable difficulty, rouses Travis and Walter as she makes breakfast. Unfortunately for Ruth, neither her work at home nor outside it is appropriately appreciated, according to the male standards (Ibid., p.398). She says to Walter who is in one of his fits of anger, "O Walter (softly) Honey, why can't you stop fighting me?" to which he replies (Without thinking) "Who's fighting you? Who even cares about you?" (p.158)

Walter's answer is an index to the deterioration of his relationship with Ruth. This deterioration, Maitino and David (1996), observe, is "symbolic of the all-too often painful black male-black female relationship ground down by the pressures of daily living experiences" (p.137).

Woman's work outside home is an important issue for the feminist in general and black womanist in particular. In relation to this, Showalter (1977) observes, "For women... work meant labor for others. Work in the sense of selfdevelopment, was in direct conflict with the subordination and repression of women inherent in the feminine ideal" (p.22).

In the same vein, Dominelli (1994) explains that "women are always related to as bearing responsibility for others and having neither specific needs of their own nor needs that conflict with their roles as mothers, wives, or carers" (qtd. in Campell, p.90).

Moreover, the various reactions towards Ruth's untimely pregnancy and suggested abortion add thematic and structural complexity in the same way as Langston Hughes's poem "Harlem"-the source of the play's title provides no single answer to the question of what happens to dreams deferred (Lester in Fisher \& Silber, 2003, p. 248). As A Raisin is the first major dramatic work to suggest abortion as a solution to an untimely pregnancy, it is possible that Hansberry is attempting to make a bold womanist statement with this plot twist.

During the 1950s, abortion was illegal. Having an abortion could subject Ruth to severe criminal penalties since the 'doctor' she is consulting is not a conventional physician but a woman who has the capability of performing an illegal abortion.

In general, twentieth century [black] feminist attitudes towards human abortion range from complete refusal of this practice, equating it with genocide and unspeakable crime (Kopaczynski, 1995, p.5) to an affirmation of woman's absolute right to refuse to have an unwanted child and to have control over the functions of their own bodies (Ibid). 
The attitudes of the Younger family are as varied as the feminists'. Except Mama who heartily welcomes the news of Ruth's pregnancy, Ruth, Water, and Beneatha are reluctant to have the new baby since this means the need for more space, food, and care. As a matter of fact, their attitudes reflect the challenges they are facing on a day-to-day basis.

Koloze (2003) believes that Ruth's attitude toward abortion, if not an accurate assessment of her attitude toward her unborn baby, position her as one who is oppressed in two ways: being a woman and being a black. (p.2) Much like mothers today who are faced with economic uncertainties and psychological pressures, Ruth seems ineluctably drawn to abortion as a solution to the problem of an unwanted pregnancy. (Ibid)

Koloze goes on to explain the nature of Ruth's dilemma. He points out that Ruth is terribly aware of what is now identified as a post-abortion syndrome, "the symptoms of psychological, physical, and emotional distress which many women who have had abortion experience, if not immediately, then years after their abortions" (Ibid). "Ain't nothin' can tear at you like losin' your baby" (p.124), Ruth proclaims in sympathy as Mama relates the story of how she and Big Walter lost one of their already born children, "Little Claude." (Ibid)

Moreover, some critics are quite clear about the effect of abortion on African-American mothers. In her 1986 essay, "Apostrophe, Animation, and Abortion," Barbara Johnson writes that "the world that has created conditions under which the loss of a baby becomes desirable must be resisted, not joined. For a black woman, the loss of a baby can always be perceived as complicity with genocide." (qtd in Koloze, 2005, p.3). Through Ruth's decision to abort, Hansberry indirectly criticizes the vicious cycles of poverty and discrimination which black families fall victim to and which force black women to resort to this unpleasant solution.

Beneatha, mostly for economic reasons, defends Ruth's right to have an abortion. She firmly rejects the old notions of childbirth and reproduction without better conditions and opportunities for a good rearing and teaching of the new generation. Otherwise, she prefers abortion and birth control. Indignant of her mother's claim that she knows nothing about birth control and that it is better for her to "mind [her] own business," Beneatha insists "It is my business-where is he going to live, on the roof?(There is silence behind the remark as the three women react to the sense of it)" (p.135).

Unlike Beneatha, Mama is a pro-life womanist. As usual, Mama proves herself a source of help to Ruth when the latter tells her she is pregnant with a child she is not sure the family can support. Mama understands Ruth's fears and depression when she explains to Beneatha, "She be all right. Women gets right depressed sometimes when they get her way," and (Speaking softly, expertly, rapidly) Now you just relax...Just lean back, don't think 'bout nothing...nothing at all" (p.135). Mama's understanding of Ruth's crisis clearly shows that she is in tune with the conflicting needs and desires of each member of her family. Her saintliness shows through here strongly as she takes on the problems of Ruth as her own. She is able to empathize strongly with her daughter-in-law, suffering as she suffers, making Ruth's needs paramount.

Walter's lack of response to Ruth's threat to have an abortion is most shocking to his mother. Unlike his father who was nearly destroyed by the death of his child, Walter has given up hope not only for himself but for his progeny. He has begun to believe that his efforts have no point. Domina (1998) claims that Walter "will be able to assume responsibility for his family again only to the extent that he can believe his life presents real choices" (p.2).

More important, when Mama confronts him with the possibility that Ruth will have an abortion, she is quite clear in her definition of the African-American race as a life-affirming people in act one, scene II:

I'm waiting to hear how you be your father's son. Be the man he was... Your wife say she going to destroy your child. And I'm waiting to hear you talk like [your father] and say we a people who give children life, not who destroys them...I am waiting to see you stand up and look like your daddy and say we done give up one baby to poverty and that we ain't going to give up nary another one...(p.149)

Mama's life-affirming statements come in two categories: first, descriptions of the love which Big Walter, the deceased patriarch of the family, had for his children; and secondly, her own definitions regarding the black race's role in preserving life. "He was one man to love his children...crazy 'bout his children!"(124-5) she relates of Big Walter. When she says this, Mama was recalling the abject poverty into which she and her husband raised their family. Mama narrates to Ruth how frequently Big Walter would come home from work and, after staring miserably at his poor surrounding, find solace in his children (Koloze, 2003, p.1).

Finally, Anne Cheney's biography of Hansberry demonstrates how Ruth's characterization is intertwined with Walter's. Although admittedly one of the "three strong, human women," with which Hansberry has populated her play, "At thirty, Ruth is caught between the ideas of the new and the old. She is a full-time domestic, but she values her roles as a wife and mother" (qtd in Ibid., p.7). Furthermore

As exhausted as Ruth is from domestic work for whites, her pregnancy, and her tension with Walter, she does not share Walter's monomania about money, business and social position. She would be satisfied with a peaceful home life and an adequate income. But as she begins to understand the compulsion of Walter's dream, their relationship becomes closer. Even Ruth's unselfish willingness to have an abortion shows her understanding of Walter's plight: she does not want to add to the financial burden or to the crowd apartment with one more person. (Ibid.)

The third woman in A Raisin is Beneatha who, according to Ben Keppel has traditionally been treated as Hansberry's alter ego, the vehicle for the expression of her creator's pan-Africanism...However, Beneatha....also expresses Hansberry's [black] feminism-her frank questioning of traditional male-female sex roles and of the assumption, 
prevalent in the fifties, that a young woman's first job was to "catch" a "good" husband and make a "good" marriage. (qtd. in Ibid., p.4)

Beneatha appears as a new and an emerging voice that has not yet come into her own. She is influenced by the new ideas of her time and is at crossroads between black poverty and joining the status of the black bourgeois. A college student, Beneatha has certain privileges that her family lacked- membership in a play-acting group, and horse back riding club, in addition to photography and guitar lessons. Commenting on this, Domina (1998) remarks that Beneatha still believes "the world offers her a variety of choices" (p.3). In relation to this, her aspirations of becoming a doctor, and not a nurse, challenges the psychological limitations that her racist and sexist society has for young black women. She is challenged by the other characters for not conforming to their notions of a black woman's role and behavior.

Hansberry makes Beneatha her mouthpiece on more than one subject. In suggesting that she will never marry the wealthy Murchison, Beneatha is introducing one of the most important themes in womanism, i.e., the role of black women in the world and the proper relationship between man and woman (Ibid., p.7). Beneatha in fact shocks Mama and Ruth not only because she considers declining an offer of wealth but also because she considers declining marriage altogether; a possibility that runs counter to their expectation of a woman's role. Through Beneatha, Hansberry proposes that marriage is not necessary for women and that women can and should have ambitious career goals. In this, she seems to agree with Maria Grey who believes that

So long as marriage is held out as the only aim of a girl's life,... so long will all attempts at improvement fail...marriage should not be the first object of a woman's life, any more than of man's; girls must be trained from childhood to the idea that they, like their brothers, must take their share in the work of life... They should not only be allowed, but induced to work for their maintenance. (qtd in Harrison, 1971, p.148)

In doing so, Beneatha proves an early womanist who radically views her role as self-oriented rather than familyoriented. She not only wants to have a career, but also desires to find her identity and pursue an independent career without relying solely on a man. Commenting on black women's attempts to resist societal stereotyping of them through education and personal achievement, Ryan (1975) says "It was by no means uncommon to find black girls who were intent upon resisting the allure of ghetto street life and applying themselves to educational attainment and career preparation" (p.390). It is clear that Beneatha is not contaminated by the deep-seated resistance to achieve worldly achievement which the psychologist Horner (1972) calls "fear of success." Women who suffer this disturbing symptom feel that career achievement, particularly competitive ones which necessitate rivalry with men, will jeopardize their femininity and marital prospects. In other words, to succeed in one way in achieving a task means failure in another task (See pp.160-173).

Moreover, Beneatha's romantic encounters with Murchison and Asagai reveal that male chauvinism and prejudice against woman transcend cultural, national, educational and economic boundaries (Lester in Fisher and Silber, 2003, 247). Like Walter's attitude, Bemeatha's efforts to discover herself as an independent black female are challenged by Murchison and Asagai's desire to force her into traditional gender roles that hinder her creativity and personal life experience. (Ibid.) For example, despite Beneatha's intellect and daringness to consider various avenues towards selfdiscovery, Murchison's interest in her is solely romantic and sexual: "You're a nice-looking girl...That's all you need, honey...Be glad for that. As for myself, I want a nice-simple-sophisticated girl—not a poet" (p.166).

Like Murchison, Asagai believes that woman is good for nothing except a comfortable marriage. According to Lester, Asagai's philosophical challenges prove empty when they undermine Beneatha's personal potentials.( in ibid., 2003, p.247) Furthermore, his sexist, Afrocentric worldview presents men as leaders and thinkers and relegate women to a secondary position, not as men's partners but as their followers (ibid.)

My dear, young creature of the New World...the African Prince [himself]...swept with the maiden back across the middle passage over which her ancestors had come-Nigeria. Home. I will show you our mountains and our stars; and gave you cool drinks from gourds and teach you the old songs and ways of our people. (pp.192-3)

Asagai believes Beneatha can be complete only through marriage to him and becoming his American cultural conquest, a symbol of his own vain glory.

More important, in her attempt to overcome an identity crisis, Beneatha insists on investigating her African heritage and culture. In doing so, she precedes the New African Movement of the 1960s, in which the black American embraced their racial history, stopping their attempts to assimilate, even in physical appearance. With pride, Beneatha wears the African robe that Assagai has given her, plays African music on the phonograph, tries to imitate an African dance, and become conscious of her artificially straightened hair after Asagai playfully refers to it as "mutilated." (See act 2, Scene 1) Beneatha wants to break free of conforming to the white ideal. Her new radical Afro-hairstyle represents her embracing of her African roots. Her cutting of her hair is a very powerful social statement, as she symbolically declares that natural is beautiful which prefigures the 1960s cultural credo that black is beautiful.

Like many black women in American society, Beneatha is placed in a very difficult position. She is exposed to fair white role models whom she can neither emulate nor achieve. The black woman fosters fantastic dreams to "look like a movie star...like one of the sweet little white girls who were everybody's dream of what was right with the world" with the aid of bleaching and straightening potions (Maya Angelo qtd in Ryan, 1975, p.373). Kenneth Clark finds such aspirations as "psychic disease" which pervaded the black slums in America (qtd. in ibid.). 
The questions of the position of woman and the nature of the roles she should play have taken the entire attention of human societies since their infancy. Since its emergence as a distinctive literary type in the $5^{\text {th }}$ century B.C. drama shows an interest in woman-related issues. However, these issues were not the main focus of the dramatic works. In fact, they were dealt with within the larger framework of the dominant patriarchal system in which women have no voice and are often relegated to secondary positions.

Due to the dramatic changes and the introduction of new ideas that took place in the twentieth century, drama witnessed a surge of interest in these issues. Of special importance to Hansberry's $A$ Raisin is the emergence of 'Womanism' since it deals with the lives of three black women who endure a double blow not only because they are black, but also because they are women as well.

When Hansberry wrote A Raisin, Womanism had not fully surfaced on the American literary scene. Here lies the importance of this powerful drama which deals with and foreshadows a number of the womanist issues that are crucial to black women's existence.

Some of the issues that Hansberry as a womanist cared about are racism, sexism, class and gender oppression, female representation in public and private life, and sterilization. Her portrayal of the three black women in the play challenged prevalent stage stereotypes of black women and introduced womanist issues to the American stage in a compelling way. Her portrayal of Beneatha as a young black woman with aspirations to be a doctor and independent in a society that highly discriminated against the black race, and her introduction of the abortion as a solution for the problem of an untimely pregnancy in an era when abortion was illegal signaled early on Hansberry's womanist stances and ideas. Indeed, in addressing these womanist issues, Hansberry proves herself a head of her time.

In fact, the play offers a rich field of exploration for American society's perception of black woman in the 1950s. Recent interpretations of female characterizations in the play reevaluate the moral strength of the three black women in many crucial ways. Instead of following the lead of traditional analyses of female characters whose reductive generalizations limit black women to passive secondary roles, current studies recognize the importance of black females as active agents in their societies.

Although the play is open-ended in the sense that it does not provide clear-cut answers to the questions it raises, it succeeds in raising the awareness of the problems the black race in general and black women in particular, are facing in a highly racist and material society. For example, the play says nothing about what is in store for the Younger family after their move to the Caybourne Park which is a clear challenge to the white racist housing policies. Similarly, the status of Beneatha'a education remains ambiguous especially in the light of Walter's loss of her share of money to Willy Harris. Perhaps, she will eventually become disillusioned after she experiences more racism and discrimination in the work market. The play also remains silent about the question of Ruth's abortion. Whether Ruth will abort the child or not is not clear. Ambiguity also envelops Walter's future economic status in the light of his loss of money and his lack of qualifications necessary to compete in the work market. In spite of this, A Raisin remains important as a cultural document about a crucial period in the history of America as well as for the continued debate over racial and gender lines that it has helped to spark. It also proves Beauvoire's above-stated belief, as far as black women are concerned, that "emancipation of [black] women is an ongoing endeavor, one that can not be complete as a project in the present." Due to her untimely death, Hansberry did not finish this project, she handed over the torch of fighting and resisting the oppression of black woman to future black womanist writers.

Finally, the writing and the production of A Raisin can be considered one of Hansberry's most radical statements. It is no small feat given her status as young black women in the 1950s. She was the youngest playwright, the fifth woman, and the only black writer at her time to win the New York Drama Critics' Circle Award for the Best Play of the year.

\section{REFERENCES}

[1] Abrams, M. H. (1999). A glossary of literary terms. (6th ed.). Boston: Heinle \& Heinle.

[2] Aston, E. (1995). An introduction to theatre and feminism. New York: Routledge.

[3] Aston, E.(1999). Feminist theatre and practice: A handbook. London: Routledge.

[4] Bolton, M. K. (2000).The third shift: Managing hard choices in our careers, homes, and lives as women. San Francisco: Jossey Bass.

[5] Bressler, C. E. (2007). Literary criticism: An introduction to theory and practice. New Jersey: Pearson Education Inc.

[6] Case, sue-ellen. (October 1985). Classic drag: The greek creation of female parts. Journal of Dramatic Theory and Criticism $\operatorname{viii(2),~317-327.~}$

[7] Campell. K. (1994). Introduction: matters of theory and practice- or, we'll be coming out the harbor. In Kate Campell (Ed.), Critical feminisms: Argument in the disciplines (pp.1-25). Buckingham: Open University Press.

[8] Changefoot, N. (2006). Equality, difference feminisms and Simone de Beauvoire's the second sex. Retrieved March, 15, 2011 from www.cpsa.acsp.ca/papers-2007/changefootH4b.pdf.

[9] Coleman, S. R. (2003). Dashiki theatre project: Black identity and beyond. Diss. of Loiusiana State UP.

[10] Domina, L. (1998). Understanding A Raisin in the sun: A student casebook to issues, sources, and historical documents. Westport, CT.: Greenwood Press.

[11] Dominelli, L. (1994). More than a method: Feminist social work. In Kate Campell (Ed.), Critical feminisms: Argument in the disciplines (pp. 83-107). Buckingham: Open University Press.

[12] Elam, H. J. and David K.(Eds.). (2001). Blacks performance and theater history: A critical reader. New York: Oxford UP.

[13] Fergusson, M. A. (1977). Images of woman in literature (2nd ed.). Boston. Joughton Mifflin Company. 
[14] Fortier, M. (2002). Theory/theatre: An introduction. London: Routledge.

[15] Ghani, H. K. (2011). I have a dream: Racial discrimination in Lorraine Hansberry's a raisin in the sun. Theory and Practice in Language Studies. 1(6), 607-614.

[16] Giles, F. S. (2005). In their own words: Pearl Cleavage and Glenda Dickerson define womanist theatre. Retrieved April, 12, 2011 from www.uga.edu/womanist/giles2.1.htm.

[17] Hansberry, L. (1960). A Raisin in the sun. In Four contemporary American plays. Selected with Biographical Notes by Bennett Cerf. New York: Vintage Books.

[18] Hanson, K. (2006). Stage(d) mothers: Mother-daughter tropes in twentieth century American drama. Diss. of Louisiana State University.

[19] Harrison. J. F. C. (1971). The early Victorians: 1832-1851. London: Iowe \& Brydone Ltd.

[20] Horner. M. S. (1972). Toward an understanding of achievement-related conflicts in women. Journal of Social Issues 28, 160173.

[21] Koloze, J. J. (2005). Abortion in the African-American community: sociological data and literary examples. Retrieved January, 5, 2011 from www.blackinformant.com/.../lifeissues.net.com_writers_Kol_kol_17aborafricanamerican-html_itihod40.pdf.

[22] Koloze, J. J.(2003). "We a people who give children life: pedagogic concerns of the aborted abortion in Lorraine Hansberry's a raisin in the sun. Retrieved December, 10, 2010 from http://life issues.net/writers/kol/osraisinin the sun.html.

[23] Kopaczynski, G. (1995). No higher court: Contemporary feminism and the right to abortion. Scranton, PA: Scranton U.P.

[24] Lester, N. A. (2003). Seasoned with quiet strength: Black womanhood in Loarraine Hansberry's a raisin in the sun. In Jerilyn Fisher \& Ellen S. Silber (Eds.). Women in literature: Reading through the lens of gender (pp.246-249). Westport Ct.: Greenwood Press.

[25] Maitino, J. R. \& David R. P. (Eds.). (1996). Teaching American ethnic literatures: Nineteen essays. Albuquerque: New Mexico UP.

[26] Rackin, P. (October 1985). Anti-historians: Women's roles in Shakespeare's histories. Journal of Dramatic Theory and Criticism viii(2), 329-340.

[27] Reed, P. Y. A. (2001). Africana womanism and African feminism: A philosophical, literary, and cosmological dialectic on family. The Western Journal of Black Studies 25(3), 168-187.

[28] Rose, H. (1989). Women's work: Women's knowledge. In Juliet Mitchell \& Anne Oakley (Eds.). What is feminism (pp.161183). London: Basil Blackwell.

[29] Ryan. M. P. (1975). Womanhood in America: From colonial times to the present. New York: New Viewpoints, A Division of Franklin Watts.

[30] Showalter, E. (1977). A literature of their own: British woman novelists from Bronte to Lessing. New Jersey: Princeton UP.

[31] Terkel, S. (April 1979). Lorraine Hansberry: Interview. Freedomways 19, 184-251.

[32] Weedon, C. (1987). Feminist practice and post-structuralist theory. Oxford: Basil Blackwell Ltd.

[33] “Womanism." (2007). Retrieved January, 20, 2011 from www.en.wikipedia.org/wiki/womainism.html.

Hana' Khalief Ghani was born in Baghdad 1969. PhD in English literature from Baghdad University, College of Arts, Department of English (2005). B.A (1991) and M.A (1999) in English literature from University of Al-Mustansiriya, College of Arts, Department of English. Major Fields of study include English Literature, Modern English and American Drama, Greek Tragedy and comparative Studies.

She is working a teaching staff in University of Al-Mustansiriya, College of Arts, Department of Translation (2004-). She worked in Baghdad University, College of Arts, Department of English (1999-2003). She published more than nine papers inside Iraq. She also translated five books into Arabic. 